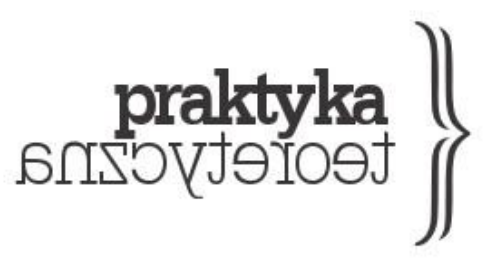

Praktyka Teoretyczna

Numer 4(18)/2015

ISSN 2081-8130

DOI: $10.14746 /$ prt.2015.4.12 www.praktykateoretyczna.pl

\title{
POMYŚLEĆ MATERIALIZM OD NOWA
}

\author{
JAKUB KRZESKI
}

\begin{abstract}
Abstrakt: Warren Montag w swojej książce Althusser and His Contemporaries: Philosophy's Perpetual War (2013) zaproponował spojrzenie na dzieło Louisa Althussera przez pryzmat jego relacji z jemu współczesnymi, ale przede wszystkim jego lektury Benedykta Spinozy. W niniejszym artykule recenzyjnym autor podejmuje się zarówno rekonstrukcji, jak i oceny tej próby, skupiając się na wydobyciu heretyckiego wymiaru materializmu uprawianego tak przez niderlandzkiego filozofa, jak i francuskiego marksistę.
\end{abstract}

Słowa kluczowe: Warren Montag, Louis Althusser, Benedykt Spinoza, teoria lektury, ideologia, struktura. 
Jeśli więc filozofia filozofów jest tą bezustanną wojną (której kres próbował położyć Kant, wprowadzając wieczny pokój własnej filozofii), to żadna filozofia nie może istnieć wewnątrz tego teoretycznego stosunku sił, dopóki nie odróżni się od swoich przeciwników i nie rozpocznie oblężenia tego odcinka pozycji, który musi okupować, by zagwarantować sobie władzę nad wrogiem, którego znamiona sama nosi.

Louis Althusser, Est-Il Simple d'Etre Marxiste en Philosophie?

W przeciwieństwie do jemu współczesnych, z którymi często łączyła go akademicka współpraca, a nawet więzi przyjaźni, Louis Althusser już za życia znalazł się na marginesie francuskiej filozofii. Choroba i morderstwo żony poprzedzające dziesięcioletni okres izolacji sprawiły, że jeden z największych dwudziestowiecznych heretyków ruchu komunistycznego ostanie lata życia spędził w zapomnieniu. Co więcej, zbliżający się nieodzownie upadek bloku wschodniego i wieszczony tryumf demokracji liberalnych nie dawały nadziei na rychły renesans myśli francuskiego filozofa.

\section{Althusser odkryty na nowo}

A jednak sprawy przybrały inny obrót. Paradoksalnie to śmierć filozofa w 1990 roku przyczyniła się do jego ponownego odkrycia. Niewatpliwie ogromną rolę odegrała również wydana dwa lata jego po śmierci autobiografia L'avenir dure longtemps (Althusser 1992). Błyskawicznie przełożona na angielski, osiagnęła niezwykły sukces wydawniczy, nieporównywalny do jego prac wydanych za życia. Dla wielu stanowiła pretekst do tropienia sensacji i szukania powiązań między fascynacją Marksem a morderstwem żony, w oparciu o wulgarną asocjację: „,marksizm = mania = morderstwo” (Elliott 2006, 322). Dla wielu innych badaczy jednak stała się pretekstem do ponowienia wysiłku lektury prac autora. Przede wszystkim tych prac, których sam Althusser nie zdecydował się przeznaczyć do publikacji. Jeśli francuskiego marksistę przez dłuższy czas można było wcześniej postrzegać przede wszystkim jako autora kilku zaledwie tekstów - W imie Marksa, Caytania „Kapitatu” czy eseju Ideologie $i$ aparaty ideologiczne państwa - zainicjowane wtedy badania, zarówno we Francji, jak i w krajach anglojęzycznych sprawiły, że dziś mamy możliwość wglądu do ogromnie bogatego dzieła ${ }^{1}$.

\footnotetext{
${ }^{1}$ Jeśli czytelniczkę interesuje całościowy obraz zarówno prac, jak i życia samego Althussera, nie sposób przecenić obszernego wywiadu z G.M. Goshgarianem - tłumaczem i autorem wielu anglojęzycznych przedmów do dzieł francuskiego filozofa - który ukazał się na łamach Viewpoint Magazine w ramach Dossier poświęconego autorowi $W$ imie Marksa. https://viewpointmag.com/2016/07/18/philosophy-and-revolution-an-interviewwith-g-m-goshgarian/
} 
Dostępne prace zmuszają do rewizji utartych interpretacji, które, jak trafnie zauważa Mateusz Janik (2014), pozostają nazbyt często fragmentaryczne. Rozpięte między wycinkowymi aplikacjami jego teorii z jednej strony a druzgoczącymi krytykami z drugiej. Krytykami, które w najlepszym razie utrwaliły obraz Althussera jako egzemplarycznego wręcz przypadku porażki w polu łączenia marksizmu ze strukturalizmem czy przyznania marksizmowi statusu nauki. W najgorszym zaś razie krytyki te sugerowały niebezpieczną bliskość antyhumanizmu z polityką stalinowską ${ }^{2}$.

\section{Althusser w filozoficznym polu bitwy}

Za postać wnoszącą olbrzymi wkład w przedsięwzięcie ponownego odkrywania Althussera może z pewnością uchodzić Warren Montag - wieloletni badacz myśli francuskiego filozofa i redaktor Décalages: a Journal of Althusser Studies, którego książka Althusser and His Contemporaries: Philosophy's Perpetual War ukazała się niedawno nakładem wydawnictwa Duke University Press. Montag oferuje czytelnikowi rodzaj szczególnej strategii lekturowej, stosując ją do niezwykle szerokiego wachlarza tekstów francuskiego filozofa. Począwszy od klasycznych prac, jak Marksizm a bumanižm czy Sprzeczność i naddeterminacja, przez rękopisy i korespondencje, po teksty, które ukazały się dopiero po śmierci Althussera. Strategia ta polega głównie na przywiązaniu do bliskiego Althusserowi myślenia o filozofii jako o teoretycznym polu bitwy (Kampfplatz), gdzie ciagle dochodzi do starć między sprzecznymi ze sobą tendencjami. Stawką tej niekończącej się walki jest zdobycie pozycji zajmowanych już przez przeciwnika (Althusser 1976, 165-166). Montag słusznie wskazuje, że to przywiązanie do militarystycznego języka jest dla Althussera czymś znacznie więcej niż tylko zabiegiem retorycznym. Pod postacią wojskowych metafor kryje się przekonanie ugruntowane w jego lekturze Spinozy, ale przede wszystkim Machiavellego, że strategia zarówno w polityce, jak i w filozofii jest rzeczą nieodzowną. Tym samym filozofii należy przyglądać się przez pryzmat rzeczywistych efektów, jakie wytwarza. Dlatego też kolejnym krokiem Montaga jest ulokowanie Althussera w „filozoficznej koniunkturze” jego własnych czasów. Autor Czyytania „Kapitału” sam scharakteryzował ją w jednym z wygłoszonych w latach sześćdziesiątych dwudziestego wieku wykładów (Althusser 2003, 1-19) właśnie jako pole bitwy - miejsce starcia między takimi myślicielami jak Jean Cavaillès, Jacques Derrida, Claude Lévi-Strauss, Michel Foucault, ale

\footnotetext{
${ }^{2}$ Znakomitą odtrutką na tego typu kuriozalne pomysły jest lektura posłowia do polskiego wydania Filozofii Marksa Étienne Balibara. Zbigniew Kowalewski przedstawia w nim dzieło Althussera jako poszukiwanie filozoficznego wyjścia ze stalinizmu, a co za tym idzie, jako konsekwentne ścieranie się z diamatem jako „metafizyczna praktyką panowania państwowych i partyjnych aparatów biurokratycznych nad proletariatem w jego własnym imieniu" (Kowalewski 2007, 203). Dzięki choćby takim tekstom, jak W odpowiedzi Jobnowi Lewisowi, zawierającym tezę o prymacie walki klasowej (Althusser 2005), widzimy jak na dłoni zerwanie Althussera z ortodoksyjnie stalinowską tezą o prymacie rozwoju sił wytwórczych nad stosunkami produkcji.
} 
również między postaciami, które choć w tamtym czasie odgrywały istotną rolę, dziś pamiętane sa znacznie słabiej, jak choćby wietnamski filozof Tran Duc Thao - praca tego ostatniego Phénoménologie et matérialisme dialectique opierała się na obronie tezy, że marksizm jest właściwą odpowiedzią na wyzwania i pytania stawiana przez fenomenologię.

Naszkicowany wyżej punkt wyjścia Althusser and His Contemporaries wymaga jednak kilku zastrzeżeń. Po pierwsze, odruchowe posługiwanie się militarnymi metaforami może przywodzić nam na myśl wizję filozofii jako miejsca starcia dobra (materializmu) ze złem (idealizmem), tym samym prowadząc do kolejnej odsłony manicheizmu. Po drugie, pojęcie „filozoficznej koniunktury” może sprawiać wrażenie, że chodzi tu o pewnego rodzaju historycystyczną lekturę. Tymczasem Montag jest absolutnie świadomy, że sam Althusser konsekwentnie odżegnywał się od tego typu wulgarnych interpretacji (Althusser 1976, 143). W rzeczywistości francuski filozof był w swych zamiarach o wiele odważniejszy, gdyż przeciwnik w żadnym razie nie przyjmował dla niego formy koherentnego systemu - konflikt rządzi również pozornie spójnymi systemami. Althusser nie przywiązywał więc wielkiej wagi do szufladkowania filozofii. Podziały na filozofię marksistowską i niemarksistowską z czasem przestały odgrywać w jego twórczości istotną rolę. Szczególnie że sam Althusser żywił przekonanie, iż w celu skutecznej obrony marksizmu należy dokonywać teoretycznych zwrotów, prowadzących często przez myśl jawnie wręcz antymarksistowską (Montag 2013, 5). Staje się to jednak w pełni widoczne dopiero w jego późniejszych tekstach, zwłaszcza w Le courant souterrain du matérialisme de la rencontre.

Jego samego postrzegano przecież często jako filozofa strukturalistycznego, właśnie z tego powodu, że odmieniając strukturę w swoich pracach niemal przez wszystkie przypadki, teksty tworzył jednocześnie w momencie, który powszechnie uznawany jest za szczytowy okres w historii tego nurtu. Takie odczytania oznaczałyby jednak, że tekst daje sprowadzić się do pewnej zunifikowanej całości dzięki pracy syntezowania, albo że przynajmniej daje się go zredukować do pewnej utajonej struktury (np. Zeitgeistu), która oddziałuje na wszystkie jego elementy - mówimy więc o interpretacji, która Montag w swojej pracy usilnie próbuje podważyć ${ }^{3}$. Widać to doskonale w trzech kolejnych częściach książki - każda poświęcona jest innemu przedmiotowi teoretycznemu stanowiącemu stawkę myślenia Althussera - strukturze (rozdziały 1-5), podmiotowi (6-8) i parze pojęciowej geneza/kres (9-10).

\footnotetext{
3 Sam Althusser odnosił się zresztą bardzo krytycznie do okresu uznawanego powszechnie za okres strukturalistyczny w jego twórczości, poddając głębokiej krytyce jej teoretycystyczny charakter. Jednocześnie odżegnywał się wyraźnie od prób przypisywania mu miana strukturalisty. W Éléments d'autocritique, tekście, w który rozlicza się ze swoim dorobkiem z lat sześćdziesiątych dwudziestego wieku, Althusser ujmuje to bardzo dobitnie: "Jeśli nigdy nie byliśmy strukturalistami, możemy w końcu wyjaśnić dlaczego: dlaczego sprawialiśmy takie wrażenie, mimo że nimi nie byliśmy, i skąd wzięło się to dziwne nieporozumienie, na którego gruncie pisano całe książki. W rzeczywistości byliśmy winni równie silnej i kompromitującej pasji: byliśmy spinozystami” (Althusser 1976, 132).
} 


\title{
Problem lektury
}

Z kwestią lektury i sposobem czytania Althussera wiążę się być może najbardziej kontrowersyjna teza Althusser and His Contemporaries. Przekonanie, że cały projekt filozofa ciążył $\mathrm{w}$ stronę spinozyzmu nawet $\mathrm{w}$ tych momentach, gdy sam autor Etyki nie był wymieniany z imienia (Montag 2013, 86). Teza ta jest o tyle trudna do obrony, że choć Spinoza wspominany jest przez cały okres twórczości francuskiego marksisty, natura tych nawiązań pozostaje często enigmatyczna. Dostrzeżeniu w niderlandzkim filozofie ,„jedynego bezpośredniego poprzednika Marksa" (Althusser i Balibar 1975, 153) towarzyszy często brak jakichkolwiek odniesień czy komentarzy ${ }^{4}$. Montag jest jednak świetnie przygotowany do tej konfrontacji. W rzeczywistości autor Althusser and His Contemporaries wykul potrzebne mu narzędzia teoretyczne znacznie wcześniej - pracując na styku myśli Spinozy i Althussera, problemowi lektury poświęcił jeden z rozdziałów Body, Masses, Power (Montag 1999, 1-25) oraz jeden ze swoich wczesnych esejów (Montag 1993, 51-59). Podstawowym źródłem inspiracji było zaś dla niego przekonanie Althussera, że samego Spinozę należy czytać za pośrednictwem jego krytyków. Dopiero bowiem w ten sposób na jaw wychodzi prawdziwie heretycki wymiar jego filozofii. Autor W imie Marksa wyraził swój stosunek do Spinozy następująco:

\begin{abstract}
Tym, co fascynowało mnie również w Spinozie, była jego strategia filozoficzna. Jacques Derrida powiedział już wiele na temat strategii w filozofii, i miał zresztą całkowitą rację, gdyż każda filozofia jest urządzeniem walki teoretycznej, która obsadza swoje tezy niczym twierdze i przyczółki strategiczne tak, by być w stanie podczas ataku zająć teoretyczne pozycje umocnione i okupowane przez adwersarza. Przecież Spinoza zaczą od Boga! [...] Niezwykła strategia: zaczął od zajęcia naczelnej twierdzy swojego przeciwnika, czy raczej umieścił w niej siebie, jakby był przeciwnikiem samego siebie, tym samym nie wzbudzając podejrzeń, że jest w rzeczywistości ich zaprzysiężonym wrogiem, i przekierował teoretyczną fortecę w ten sposób, że wywrócił ją na nice, tak jak działa fortecy zwraca się przeciw jej własnym obrońcom (Althusser 1993, 85-86).
\end{abstract}

W powyższym cytacie Althusser nawiązuje rzecz jasna do operacji, która znamy pod postacia Deus, sive Natura - serca Spinozjańskiego systemu, stanowiącego radykalny gest zniesienia transcendencji. Wbrew wielu interpretacjom, jak przekonuje nas autor W imie Marksa, nie mamy tu jednak wcale do czynienia z jakimkolwiek równaniem, które pozwoliłoby na odwrócenie

\footnotetext{
${ }^{4}$ Jedna z najbardziej systematycznych analiz stosunku Spinozy do Althussera jest esej Petera D. Thomasa Philosophical Strategies: Althusser and Spinoza (2002, 72-113), w którym autor, wychodząc od podobnych przesłanek co Montag (problem filozofii i strategii), ukazuje zadanie wzbogacenia materializmu historycznego, jakie postawił przed sobą Althusser, świetnie odpierając zarzuty takich autorów jak Perry Anderson (1976, 64-65), którzy w najważniejszych pojęciach Althussera nie widzieli nic innego niż zadłużenie się w przedmarksowskiej metafizyce, a tym samym wycofanie się na przedkrytyczne pozycje.
} 
dokonanej operacji - w ten sposób, że drugi termin dałby przetłumaczyć się z powrotem przez pierwszy, co możemy obserwować w przypadku innej filozoficznej operacji Spinozy - jus, sive potentia. Zgodnie $z$ tą formuła prawo nie istnieje poza moca, którą rozumieć możemy również jako przemoc. Dokonuje się tu zatem nie tylko translacja, gdyż jak celnie ujął to Janik: „rzeczywiste znaczenie danego terminu staje się nieuchwytne, pozostawiając jedynie serię przekształceń” (2013, 233).

Kluczowym zagadnieniem dla rozwiązania problemu lektury jest zmierzenie się z wyłożona w Traktacie teologiczno-politycznym interpretacją Pisma, którego poznanie, zdaniem Spinozy, nie powinna różnić się niczym od „metody objaśniania natury” (Spinoza 2009, 483484). Choć jak słusznie zauważa Montag, Spinoza nigdy nie napisał scriptura, sive natura, to w powyższym fragmencie z łatwością dostrzeżemy tę znaną nam już filozoficzną strategię (Montag 1999, 5). Jednak co najważniejsze, to znaturalizowanie Pisma Świętego wcale nie oznacza, że działa tu jakieś prawo naturalne, które czyniłoby je całkowicie odpornym na zmiany. Wręcz przeciwnie, biorąc pod uwagę, że ogromna część wiedzy o języku hebrajskim została zwyczajnie utracona (Sharp 2011, 8), jesteśmy skazani na lekturę, która nie tylko nigdy nie będzie kompletna, ale i pod wpływem nowej wiedzy i kolejnych spotkań tekstu i czytelnika będzie zmieniać swoje znaczenie. Dlatego też zamiast mówić o inherentnym znaczeniu, jakie skrywać miałoby przed nami Pismo Święte, Spinoza przekonuje nas, żebyśmy spojrzeli na nie jak na każde inne ciało, a co za tym idzie, skupili swoją uwagę na efektach, jakie produkuje jedna zaś z najważniejszych właściwości ciała jest zdolność do pobudzania i bycia pobudzanym. To właśnie dzięki temu tekst staje się podatny na otwarcie i pozwala swoim czytelnikom na dokonanie interwencji, z czego użytek czyni Althusser w Cåytaniu „Kapitału” (Althusser i Balibar 1975, 34). W tym sensie spotkanie jednego ciała z drugim wyprodukować może różne efekty w zależności od ich konkretnych złożeń. To właśnie dzięki tak rozumianej teorii materialności lektury Montagowi udaje się uchwycić relację łącząca Althussera ze Spinozą i prześledzić ich wzajemne oddziaływanie na siebie:

idąc tropem jednych hipotez przeciw drugim i forsując je tak, by dochodziły do ostatecznych konkluzji, do rozbrajania teoretycznego aparatu, w którym dominuja pojęcia transcendencji, niematerialności czy idealizmu. Interwencja ta zaowocowała materializmem tak bezkompromisowym, że pozostał on dla krytyków Althussera, jak i krytyków Spinozy trzysta lat wcześniej, niezrozumiały i nie do pomyślenia (Montag 1993, 52). 


\section{Spinozjańska interwencja}

Montag stoi na stanowisku, że podobnie jak Althusser dokonywał ingerencji w siły konstytuujące dzieło Spinozy, tak i Spinoza interweniuje w teksty samego Althussera. Odwrócenie tej relacji ma pomóc w wydobyciu na wierzch śladów tego bezkompromisowego i heretyckiego materializmu, który Althusser dostrzegł w tekstach autora Etyki. Dlatego też kolejne rozdziały Althusser and His Contemporaries to nic innego jak właśnie próby rozpoznania tendencji i wyznaczenia sił konstytuujących teksty francuskiego marksisty, a następnie uchwycenia ich we wzajemnym klinczu. Widać to doskonale już od pierwszej części poświęconej strukturze, w której obserwujemy pełen napięcia stosunek Althussera do tego pojęcia. Montag, rekonstruując krytykę autora $W$ imie Marksa wysuniętą pod adresem antropologii Lévi-Straussa, w którego tekstach Althusser dostrzegał pewne widmo idealistycznego ujęcia totalności jako ukrytego poruszyciela, pokazuje, jak francuski marksista wpada w tę samą pułapkę. Ma to miejsce w Cazytaniu „Kapitału”, gdzie autor wprowadza pojęcie struktury jako utajonego porządku. Dopiero korespondencja z Pierre'em Macherey'em, który zwrócił mu uwagę na idealistyczną tendencję w jego własnych zmaganiach, i dalsza konfrontacja z pracami jego ucznia i współpracownika zmusiły Althussera do powrotu do tego zagadnienia, dając pretekst do jego przeformułowania. Polskie wydanie Czytania „Kapitału”, podobnie zresztą jak większość jego tłumaczeń, oparte jest na drugim, poprawionym wydaniu francuskim z 1968 roku. W rzeczywistości polskojęzyczna czytelniczka nie tylko zatem nie ma dostępu do zawartych w pierwotnej wersji tekstów Jacques'a Rancière’a, Macherey'a i Rogera Estableta, ale również nie ma możliwości prześledzenia zmian, jakie Althusser naniósł w międzyczasie we własnych fragmentach, kluczowych z perspektywy argumentacji Montaga. Sa one bowiem jedyną odpowiedzią na przedstawione przez Macherey’a zarzuty - niestety nie powstała z tego osobna książka. Dla Montaga jednak interwencja Macherey’a, o wyraźnie spinozjańskim charakterze, mimo że nie doczekała się nigdy odrębnej odpowiedzi ze strony Althussera, dała początek innej tendencji w jego myśleniu. Tendencji biegnącej w poprzek takich krytyk jego prac, jak te autorstwa E.P. Thomsona czy Rancière’a, którzy w Althusserze dostrzegali przede wszystkim filozofa porządku. Tymczasem poprawione w drugim wydaniu zakończenie Prz̧edmiotu „Kapitatu” staje się podstawą spinozjańskiej interpretacji struktury, w myśl której rozumiana jest ona jako „nieobecna przyczyna określonego nieładu” (Montag 2013, 79).

Podobny klincz i starcie tendencji obserwujemy w drugiej części omawianej publikacji. W całości jest ona poświęcona problemowi podmiotu postrzeganego przez pryzmat tekstów o ideologii. Podstawę kreślonego tu przez Montaga konfliktu stanowi napięcie między dwoma tendencjami - ortodoksyjnego ujmowania ideologii przez pojęcie reprezentacji i obecnej już w pierwszych pracach dotyczących tego zagadnienia tendencji do myślenia o ideologii jako 
materialnej praktyce. To zresztą w tej części obrany przez Montaga sposób lektury sprawdza się najlepiej, pozwalając mu wychwycić sprzeczności na poziomie poszczególnych tekstów i ukazać próby ich przezwyciężenia. Konflikt reprodukowany jest jednak na kolejnych etapach, tworząc kolejne aporie. Autora rzecz jasna w tej części interesuje przede wszystkim tendencja do myślenia o ideologii poza kategoriami świadomości. Choć Althusser nie rezygnuje z posługiwania się samym pojęciem świadomości, w pewnych momentach podlega ono u niego filozoficznej operacji, która znamy już pod postacia przekształcenia, spinozjańskiego sive. Widać to najlepiej w Ideologiach $i$ aparatach ideologicznych państwa, gdzie Althusser pisze wprost: „»Świadomości«, to znaczy zachowaniach jednostek” (2006, 27). Świadomość, podobnie, jak Spinozjański Bóg, została poddana całej serii przekształceń, po których nie sposób już poznać wyjściowego pojęcia. Montaga interesuje jednak niemożność zsyntetyzowania tego ujęcia z przeciwnymi tendencjami, przede wszystkim $z$ interpelacja jednostek do zostania podmiotami. Althusserowi nie udało się tu do końca pozbyć pewnego dramatu uznania, a co za tym idzie, myślenia za pomocą kategorii świadomości i intersubiektywności (Montag 2013, 165). Być może najbardziej problematycznym elementem tej części jest odsunięcie na bok kwestii postrzegania ideologii jako nieświadomości oraz niewatpliwego zadłużenia Althussera w psychoanalizie. Jednak zdaniem Montaga Lacan dla Althussera to nic innego jak kolejna spinozjańska interwencja - Lacan i jego wyobrażeniowe jest dla Althussera w Psychanalyse et sciences humaines tylko inną nazwą na Spinozjańskie pojęcie wyobraźni. To dzięki temu zabiegowi Montagowi udaje się ująć próbę odrzucenia myślenia ideologii na gruncie metafory bazy i nadbudowy, i zastapić je myśleniem w kategoriach transindywidualności (Montag 2013, 129).

Zarysowana powyżej strategia sprawdza się najsłabiej w ostatniej części książki, która nie tylko nie dorównuje pozostałym częściom pod względem objętości, ale dotyczy również znacznie węższego materiału - problem genezy/kresu zredukowany zostaje tu właściwie do dwóch tekstów francuskiego marksisty. Montag zaczyna tę część od interpretacji Le courant souterrain du matérialisme de la rencontre, podkreślając przede wszystkim pewnego rodzaju mesjanizm ujawniający się pod postacia „zasady nadziei, wyczekiwania” (Montag 2013, 185), w której stronę ciąży rozważana w tym okresie przez Althussera filozofia nicości. Trzeba przyznać, że autor robi to kosztem wątków, które wydają się znacznie bardziej interesujące z perspektywy heretyckiego wymiaru materializmu Althussera. Choćby niezwykle istotnego zagadnienia podporządkowania konieczności przygodności czy aleatorycznej interpretacji akumulacji pierwotnej i genezy kapitalizmu, która czyni przecież francuskiego marksistę jednym z najbardziej interesujących badaczy problemu przejścia z feudalizmu do kapitalizmu. Z kolei w następnym rozdziale Montag odwraca porządek chronologiczny po to, by zakończyć swoja książkę odniesieniem do tekstu napisanego przez dwudziestoparoletniego Althussera, wówczas wciąż jeszcze wierzącego katolika i piszącego na dodatek w zupełnie innej filozoficznej koniunkturze - w powojennej Francji szarpanej przez apokaliptyczne nastroje. Zdaniem 
Montaga to właśnie przeciw nim zwracał się Althusser, wykuwając teoretyczne narzędzia umożliwiające przeciwstawienie się mesjanistycznej tendencji, która odezwie się w ostatnim okresie jego twórczości.

\section{Przeoczone spotkanie}

Przywoływany powyżej Gregory Elliott określił intelektualny rozwój Althussera mianem „objazdu teorii”, relacjonując za pomocą tej metafory ciag wolt i zwrotów w twórczości francuskiego myśliciela. Czytając książkę Montaga, ciężko nie odnieść wrażenia, że amerykański badacz, sam śledząc tę drogę, zupełnie gubi właściwy horyzont. Tymczasem, jak przekonuje Étienne Balibar, nie ma wattpliwości co do kryterium stosowanego przez Althussera podczas wspomnianych objazdów. Wyznacza je możliwość implementacji polityki komunistycznej

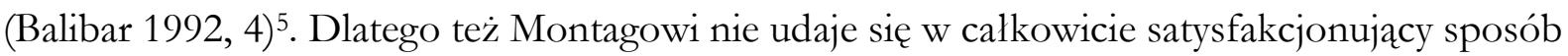
odpowiedzieć na tytułowe pytanie z przedmowy jego własnej książki: „Po co czytać dziś Althussera"? Odpowiedź pojawia się dopiero wraz ze śledzeniem toku wywodu francuskiego marksisty i podczas wnikania w sam tryb jego myślenia. Zawiera się ona w przekonaniu, że materializm historyczny to nie odziedziczona przez nas teoria, której czystości w jakikolwiek sposób trzeba bronić przed zagrożeniem z zewnątrz. Wręcz przeciwnie, żyje ona tylko w starciach, w swojej ciagłej gotowości do toczenia walki na zewnattrz, ale i do podważania samej siebie, a co więcej - pozbawiona wszelkiej obietnicy dialektycznej syntezy, musi być gotowa, by w przypadku porażki pomyśleć siebie na nowo. Althusser, który w ostatnich latach swojej twórczości krytycznie wypowiadał się o rozpoznaniu zamykającym Teşy o Feuerbachu, przekonując, że każda filozoficzna interpretacja jest uwikłana bądź w podtrzymywanie, bądź znoszenie status quo, staje się doskonałym sojusznikiem dla wszystkich, którzy występuja przeciw konieczności istnienia danych formacji społecznych i usiłują otworzyć horyzont zmiany. W tym zadaniu książka Montaga z pewnością okaże się nad wyraz pomocna.

\footnotetext{
5 Świetną uzupełniającą lektura, która pozwoli czytelniczce zobaczyć opisywane przez Montaga zwroty przez pryzmat zmian i przekształceń w światowym ruchu robotniczym, jest wstęp autorstwa Asada Haidera i Salara Mohandesiego do angielskiego tłumaczenia Sur la pensée marxiste. Redaktorzy Viewpoint Magazine uczynili punktem wyjścia swojego tekstu dokładnie to, co Montag odsuwa w swojej pracy na margines - zetknięcie francuskiego marksisty ze stalinowskimi i reformistycznymi tendencjami w ruchu komunistycznym https://viewpointmag .com/2012/09/12/underground-currents-louis-althussers-on-marxist-thought/.
} 


\section{Wykaz literatury}

Althusser, Louis i Étienne Balibar. 1975. C乏ytanie „Kapitału”. Tłum. Wiktor Dłuski. Warszawa: PIW.

Althusser, Louis. 1976. Essays in Self-Criticism. Tłum. Graham Lock. London: NLB.

Althusser, Louis. 1992. The future lasts forever: A memoir, red. Olivier Corpet i Yann Moulier Boutang. Tłum. Richard Vaesey. New York: The New Press.

Althusser, Louis. 1993. "L'unique tradition matérialiste." Lignes, nr 18.

Althusser, Louis. 2003. "The Philosophical Cnojuncture and Marxist Theoretical Research." W Louis Althusser, The Humanist Controversy and Other Writings, red. Francois Matheron. Tłum. G. M. Goshgarian. London: Verso.

Althusser, Louis. 2005. W odpowiedzi Johnowi Lewisowi. Tłum. Andrzej Staroń. Warszawa: Studenckie Koło Filozofii Marksistowskiej. http://www.filozofia.uw.edu.pl/skfm/publikacje/althusser04.pdf (dostęp: 29.07.2016).

Althusser, Louis. 2006. Ideologie i aparaty ideologicæne państwa. Tłum. Andrzej Staroń. Warszawa: Studenckie Koło Filozfii Marksistowskiej. http://www.filozofia.uw.edu.pl/skfm/publikacje/althusser05.pdf (dostęp: 29.07.2016).

Anderson, Perry. 1976. Considerations on Western Marxism. London: NLB.

Balibar, Étienne. 1992. "The Non-Contemporaneity of Althusser." W The Althusserian Legacy, red. E. Ann Kaplan i Michael Sprinker. London-New York: Verso.

Elliott, Gregory. 2006. Althusser. The Detour of Theory. Leiden: Brill.

Janik, Mateusz. 2014. „Louisa Althussera On the Reproduction of Capitalism - trzy strategie czytelnicze". Praktyka Teoretyczna 4 (14).

Janik, Mateusz. 2013. „Niedokończony projekt filozofii immanencji. O dwuznacznym stosunku Spinozy do teologii”. W Deus otiosus: Nowoczesność w perspektymie postsekularnej, red. Agata Bielik-Robson i Maciej Sosnowski. Warszawa: Wydawnictwo Krytyki Politycznej.

Kowalewski, Zbigniew Marcin. 2007. „Wyjście z materializmu dialektycznego”. W Étienne Balibar. Filozofia Marksa. Tłum. Andrzej Staroń, Adam Ostolski, Zbigniew Marcin Kowalewski. Warszawa: Książka i Prasa.

Montag, Warren. 1993. „Spinoza and Althusser Against Hermeneutics: Interpretation or Intervention?” W The Althusserian Legacy, red. E. Ann Kaplan i Michael Sprinker. London-New York: Verso.

Montag, Warren. 1999. Bodies, Masses, Power. London-New York: Verso.

Montag, Warren 2013. Althusser and His Contemporaries. Philosophy's Perpetual War. DurnhamLondon: Duke University Press.

Sharp, Hasan. 2011. Spinoza and the Politics of Renaturalization. Chicago: The University of Chicago Press.

Spinoza, Benedykt. 2009. Traktat teologiczno-polityczny. Tłum. Ignacy Halpern. Warszawa: Hachette.

Thomas, Peter D. 2002. "Philosophical Strategies: Althusser and Spinoza." Historical Materialism 10/3. 
Jakub Krzeski - student Międzyobszarowych Indywidualnych Studiów Humanistycznych i Społecznych UW, w ramach których studiuje filozofię i kulturoznawstwo. Interesuje się przede wszystkim marksizmem postoperaistycznym i społeczną myślą nowożytną. Redaktor Praktyki Teoretycznej.

\section{DANE ADRESOWE:}

Jakub Krzeski

Kolegium Międzyobszarowych Indywidualnych Studiów Humanistycznych i Społecznych UW ul. Dobra 72

00-312 Warszawa

EMAIL: j.m.krzeski@gmail.com

CYTOWANIE: Krzeski, Jakub. 2015. Pomyśleć materializm od nowa. Praktyka Teoretyczna 4(18): 240-250.

DOI: $10.14746 /$ prt.2015.4.12

AUTHOR: Lukasz Moll

TITLE: Rethinking Materialism

ABSTRACT: In his book Althusser and His Contemporaries. Philosopby's Perpetual War (2013) Warren Montag proposed an interpretation of Louis Althusser's work through engagements with Althusser's own contemporaries but above all through his engagement with Baruch Spinoza. This review essay is an attempt to both reconstruct and evaluate this attempt by showing heretical nature of Althusser's and Spinoza's materialism.

KEYWORDS: Warren Montag, Louis Althusser, Baruch Spinoza, theory of reading, ideology, structure. 